\title{
Spatial Economic Development of Mecca Region, Saudi Arabia
}

\author{
A. K. Alhowaish ${ }^{1}$, Ahmed Bafgeesh ${ }^{2}$, Abdulrahman Aljarboe ${ }^{3}$ \\ ${ }^{1}$ Associate Professor, University of Dammam, College of Architecture \& Planning, \\ Department of Urban and Regional Planning, P.O. Box 2397, Dammam 31451, Saudi Arabia \\ ${ }^{2,3}$ Master Students at University of Dammam, College of Architecture \& Planning, \\ Department of Urban and Regional Planning, P.O. Box 2397, Dammam 31451, Saudi Arabia
}

\begin{abstract}
This research aims to study and analyze the economic structure of different economic activities in Mecca region in Kingdom of Saudi Arabia, in order to identify the possibilities and elements of spatial economic development, then to give recommendations achieving regional economic environment attracting investment opportunities and career opportunities on one hand, and to support directives of national development plans on the other hand. The following questions will be answered throughout this research paper: What characterizes Mecca region economically? What are the main economic activities of competitive and comparative advantages in the region? Study also recommends focusing on wholesale activities and retail trade activities, repairing of motor vehicles and motorcycles, and constructive activity which engaged about 30.6\% of total number of labor in Mecca region, reflecting strength of economic activities by attracting investment capitals, job opportunities and income for the region and its residents, in addition to adopting developmental polices and strategies making its growth and development continuous. Agriculture, forestry, fishing, mining and utilizing stone pits activities, financial and insurance activities, scientific and technical professional activities, supply of electricity, gas, steam and air conditioning, public administration and defense, compulsory social security, education, arts, recreation and entertainment are considered activities in the presence of spatial elements (geographic location and promising economic tourist areas in Mecca region, especially with high level of developmental activities in the region, insuring existence of promising future investment opportunities for these activities in the region. Study recommends adopting policies and motivational programs, and reinforcing ability of the region to develop these opportunities through private sector.
\end{abstract}

Keywords: Economic structure, sectors of economic activities, spatial economic development, Mecca region, Kingdom of Saudi Arabia.

\section{Introduction}

Saudi Arabian's economy has achieved significant developments over the past decade, but it is necessary to increase the diversification of the economic base. According to the Ninth Development Plan in the Kingdom of Saudi Arabia "the diversification of the production base of economic development has remained since beginning of planning process for development of the Kingdom. Its main objectives and strategic bases were achieving development balanced between regions of the kingdom on one hand, and reducing development gap between the cities and villages of the same region on the other hand. Target which almost was repeated in every five-year plan [1]. The country's interest in developing national economy represented by focusing on the overall development, so plans which insure raising of social, economic, environmental and architectural level according to safe and studied bases. This achieved many great fulfillments, make Kingdom of Saudi Arabia one of the great and best countries. The overall development option is also considered the strategic dimension of balanced and sustainable development. The overall development contributes in reducing hazards which can occur due to the nature of Saudi economy which has been - for a long period of time - a single-source economy by depending on oil, thus, the overall development is a method of achieving strategic objectives for sustainable and balanced development with all economic, social and environmental aspects.

The goal of this research is to study and analyze economic structure of different economic activities in Mecca, in order to identify the possibilities and elements of spatial economic development of Mecca region, by identifying its economic elements and its main comparative and competitive advantages, then to come up with recommendations which create regional economic environment attracting investment opportunities and career opportunities on one hand, and to support the directives of national development plans on the other hand.

To achieve the desired goal, this study will discuss and analyze the economic structure of different economic activities sectors in Mecca region and compare them, whereas the analysis will be restricted on which economically characterizes Mecca region, and analysis of the following main economic activities sectors:

1) Agriculture, forestry and fishing.

2) Mining and quarrying.

3) Manufacturing.

4) Electricity, gas, steam and air conditioning supply.

5) Water supply; sewerage, waste management and remediation activities.

6) Construction.

7) Wholesale and retail trade; repair of motor vehicles and motorcycles.

8) Transportation and storage.

9) Accommodation and food service activities.

10) Information and communication.

11) Financial and insurance activities.

12) Real estate activities.

13) Professional, scientific and technical activities.

14) Administrative and support service activities.

\section{Volume 4 Issue 12, December 2015}




\section{International Journal of Science and Research (IJSR) \\ ISSN (Online): 2319-7064}

Index Copernicus Value (2013): 6.14 | Impact Factor (2014): 5.611

15) Public administration and defense; compulsory social security.

16) Education.

17) Human health and social work activities.

18) Arts, entertainment and recreation.

19) Other service activities.

20) Activities of households as employers; undifferentiated goods-and services-producing activities of households for won use.

21) Activities of extraterritorial organizations and bodies.

Importance of this study appears in achieving a breakthrough in balance development level with its all social, economic, architectural and environmental aspects between regions of the Kingdom on one hand and the provinces of each region on the other hand, which required by five-year national development plans, by reducing the severity of regional developmental disparities and achieving balanced development, in addition to supporting of national development and achieving higher level of diversification in structure of national, regional and local economy. We will identify and analyze - in this research - the possibilities and elements of spatial economic development of Mecca region. figure(1) shows the location of Mecca, the area of study[2], which involves $137,000 \mathrm{~km}^{2}$ area, as area of Mecca is estimated about 2,250,000 $\mathrm{km}^{2}$, and the population of Mecca are 7.2 million peoples which equals $25.5 \%$ of total population of Kingdom of Saudi Arabia [3].

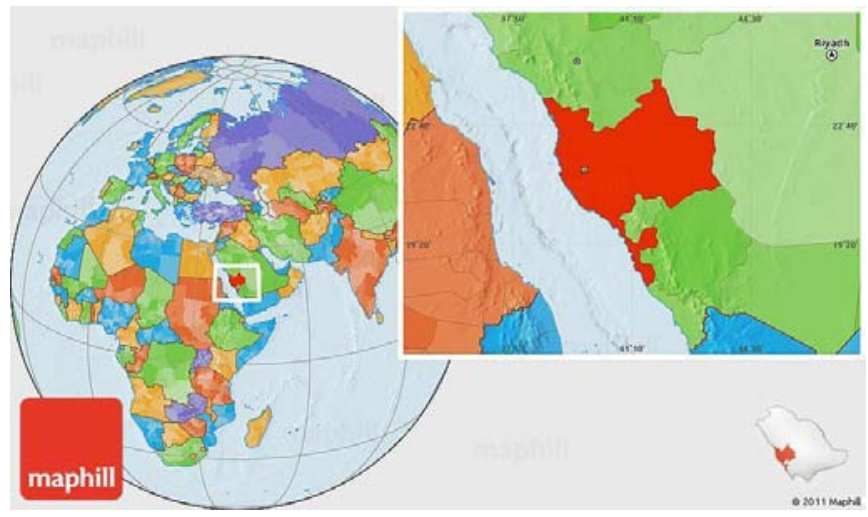

Figure 1: Map of Mecca

Mecca region has great importance because it includes Haram al-Sharif, the region where pilgrims target from all over the world, in addition to importance of Jeddah province which associated to Mecca with its historical commercial port as it is an advanced touristic area, as well as the role which Taif province paly as a mountain resort. The region also has well and balance economy as it is actually a center of commerce, mining and agriculture, in addition to annual activity which associated with hosting pilgrims, as well as the position made by Jeddah region as the most importance frontages on Red sea. According to these features, Mecca region has been selected as a study case, in order to achieve regional economic environment attracting investment opportunities and career opportunities on one hand and to support directives of national development on the other hand. The economic urban changes in the regions depends on its economic elements such as tourist, industry, transport and agriculture, whereas the region represents $7.2 \%$ of agricultural production of the kingdom, especially Taif agricultural city, supported by highly efficient wide regional road networks such Mecca-Jeddah, Mecca-Medina, MeccaTaif-Riyadh roads [4].

\section{Literature Review}

\section{Mecca region - General view}

The administrative boundaries of Mecca region, which called - in this research - Mecca territory, according to terms of cities geography. Study area is located in the west of the kingdom, $400 \mathrm{~km}$ away from Medina in south-west direction, $120 \mathrm{~km}$ away from Taif city in eastern direction, and $72 \mathrm{~km}$ away from Jeddah and Red sea coast. The nearest ports to it is Jeddah Islamic Port, and the nearest international airport is King AdulAziz Airport. Mecca is located at the intersection of two latitude 21/25 east, and meridians 39/49 east. The region consists of sixteen provinces which are: Mecca, Jeddah, Taif, Rabigh, Alkamel, Qunfudah, Turubah, laith, Aljmom, Khulais, Adham, Kharma, Rutba, Al Ardiyat, Al Muwayh, Maysan, and Bahra. The average of family size in Mecca is approximately five individuals [5].

The concept of population-development interrelationship has been discussed poignantly since many centuries. On one hand, Adam Smith thinks that the population growth is a motivation toward economic development because it extends size of market and provide many economic opportunities (Economy of Sale), then gives more efficient success, however Malthus and Ricardo opposed that in term of scale to return diminishing law, believing that the population growth will lead to limitation of natural resources, especially with reducing of arable lands. This situation - as they believe - leads to distention, unemployment and absolute scarcity. Then, the point of view of Hoover and Coale indicating that reducing fertility leads to reduction of subsidy, and then increasing savings and investments, which motivates economic development. In the beginning seventies of twenty century, more complex Malthus-like point of view has been appeared, by Elrich's book and Roma Club involving Limits of Growth idea, which indicates that the population growth leads to depletion of natural non-renewable resources on the surface of Earth, especially oil and minerals, in addition to degradation of the environment. Therefore, people of this idea proclaims about necessity of achieving "Zero-growth" with slowing economic growth. Then, others ideas appeared, supporting Smith's point of view who believes that the population growth motivates economic growth. The idea represents that the population growth leads to increase supply of labors which keeps the wages not to become greater, enhances activity, increases productivity and encourages creativity. In the same side, Boserup has argued that the population growth provides a motivation of technical advance by creativity of youth labors and through competition and scale of economy. There are many ideas which have been appeared in the last years ago, supporting ideas mentioned above, or opposing them.

Spatial economic development means "attaining of spatial economy structure - anywhere, anytime - the level of 


\section{International Journal of Science and Research (IJSR) \\ ISSN (Online): 2319-7064}

Index Copernicus Value (2013): 6.14 | Impact Factor (2014): 5.611

development appropriate to promotion of economic development process and supporting it efficiently.

It means that it represents positional and spatial aspects of economic development, as it integrates positional goals with national goals. Then, it is important to be considered as a holistic view including the economy completely, on the basis of spatial economic space level [6]. Therefore, the balanced spatial development bases on giving or providing a model of spatial distribution for investment projects which does not depend totally on economic factors, because depending on those factors leads to enhance development in traditional development aspect with devoting backwardness in other regions of the country [7]. Thus, the balance in development means integration in development between different centers [8]. According to that, the spatial economic development policy plays its role in guiding development plans. It aims to create a situation of relative balance in distributing sector investments between different territories, in order to reduce the phenomenon of population concentration and variation in living standards, and entering between residents of different territories (urban and rural). This policy has been initiated by idea of territorial planners, who insure the important of making works easy for residents in order to limit the immigration and to achieve spatial stability for the populations [9].

By referring to previous studies, which discussed spatial economic development in Kingdom of Saudi Arabia through last three decades; these studies has been classified into three main groups, as follows:

\section{Studies which tried to formulate comprehensive spatial developmental policies and strategies:}

They have put a comprehensive architectural strategy for the kingdom, achieving benefits from features of big urban centers on one hand, and reducing the severity of spatial disparities in development of the country, then achieving balanced development with its all social, economic and environmental aspects on the other hand, and putting a proposed strategy for spatial development in the kingdom, with three main focuses represented as social dimension, economic dimension and architectural dimension[10]. Study put proposed strategy for rural spatial development in the kingdom, reducing the severity of spatial variation between urban and rural regions within the same territory[11].

\section{Study about applying some theoretical concepts in study of spatial development:}

Study focused on the concept of center - margins in the kingdom, according to Ecological perspective. Study has focused on role of developmental plans in managing the territorial balance in the kingdom, especially the concept of attraction, center and margins[12]. Study has focused in his study of Saudi urban system on applying the concept of central place and its role in accelerating of balanced between regions of Kingdom of Saudi Arabia[13].

\section{Studies which focused on analyzing the severity of territorial variation in Kingdom of Saudi Arabia:}

Study has discussed the effect of spatial distribution of industries in the kingdom on territorial disparities[14]. While study has discussed spatial development in the two administrative regions; al-Sharqiya and Medina, in term of the role of petrochemical industries in the two industrial cities; Jubail and Yanbu in development of these two mentioned administrative cities[15]. Study has discussed spatial distribution between the thirteen regions of the kingdom[16]. Study has discussed territorial disparities of health services in the kingdom[17], and another study has discussed territorial variation in term of health and educational services, specifically, in term of variation between territories of the kingdom in availability and using of these services with taking study cases as territory samples in this regard[18]. Study has discussed classification of territories of the kingdom into three groups according to their developmental possibilities[17]. Study has focused on the role of small and medium sized cities in the spatial development of the kingdom[19].

The review of previous studies shows a number of important points which are unique to this study, including:

- Most studies has depended in analysis on wide spatial units, such as five planning territories in the kingdom, or the thirteen administrative regions of the kingdom. No study has depended on one spatial unit or one administrative region, except study for Al-Sharqiya and Medina[20]. Most important recommendations of those studies were that the future studies must be on the level of administrative regions and its associated provinces, in order to give more accurate and more detailed results about economic spatial development in regions of the kingdom separately, and this is which will be done by this study.

- The vast majority of studies have focused on measuring level of territorial disparities between reigns of the country, but did not focused on determination of developmental possibilities, generally, and spatial economic possibilities particularly, which will be done by this study.

\section{Research Methodology}

Information of this study has been obtained from associated governmental departments, especially the ministry of economy and planning represented by statistics and information survey [21]. Which contains information about different economic activities sectors, and number of labor in each economic activities on the territorial level (regional) and national level. Because of limitation of data available about economic sectors and the type of different economic activities done by governmental departments generally, and public statistics and information survey particularly; it has been focused on the number of labor in different economic activities as a major indicator in studying and analyzing economic structure of Mecca region, and identifying and determining economic comparative and competitive advantages of it, then comparing it with economic activity at the national level.

Many quantitative methods have been used to present, discuss and analyze economic structure of different economic activities sectors in Mecca region, and comparing it with

\section{Volume 4 Issue 12, December 2015}




\section{International Journal of Science and Research (IJSR) \\ ISSN (Online): 2319-7064}

Index Copernicus Value (2013): 6.14 | Impact Factor (2014): 5.611

economic activities at the national level, by functioning package of the following quantitative statistical methods:

- The percentage of concentration (Share\%) has been used for each economic activity separately [22], to clarify the amount of change in the extent of concentrating of career opportunities (number of labor) for different economic activities 2015 , by following below equations:

$$
r=\left(\frac{x_{t}-x_{T}}{x_{T}}\right) \times 100
$$

Whereas:

$r=$ Rate of change in the number of labor during the study period.

$x_{T}=$ The number of labor in the previous census.

$x_{t}=$ The number of labor in the post-census.

$$
n=\left(\frac{x_{i}}{x_{j}}\right) / 100
$$

\section{Whereas:}

$n=$ Rate of concentration in the number of labor.

$x_{i}=$ The number of labor in the economic sector (i).

$x_{j}=$ Total labor in all sectors of the economy in the region (j).

- To measure and identify which are the major activities of comparative and competitive advantages characterizing Mecca region, Location Quotient (LQ) of different economic activities has been used, because it is considered most important indicators of territorial economic activities in determining comparative and competitive advantages for each economic activity in the studied region, comparing with different economic activities in other regions in the state or in the same country [23], using the following equation:

$$
L Q=\frac{e_{i}^{t} / e_{T}^{t}}{E_{i}^{t} / E_{i}^{t}}
$$

Whereas:

$L Q=$ Location Quotient .

$e_{i}^{t}=$ Number of labor in economic activity (i) in the studied region.

$e_{T}^{t}=$ Total number of labor in all economic sectors in the studied region.

$E_{i}^{t}=$ Number of labor in economic activity (i) all over the country.

$E_{i}^{t}=$ Total number of labor in all economic sectors all over the country.

Location Quotient takes values larger, smaller or equal to "one". If L-Q value larger than "one"; this means the region is attractive to measured economic activity (investment and career opportunities) and it is exporter to outputs of activities to other regions (studied region becomes of high comparative and competitive advantages of that activity comparing with other regions), and vice versa, if value of this quotient is smaller than "one", this means that the region is repulsive to labor in measured economic activity, and it does not attract business men, subsequently the career opportunities. If the value of L-Q equals "one", this means that the region's economic activity equals the average of that activity all over the country [24].

\section{Results}

Sectors of economic activities in Mecca region:

Mecca region is characterized by many major economic activities of comparative and competitive advantages. The results of analysis of Location Quotient for economic activities show several major important points, which are:

\section{Major economic activities of Location Quotients larger than "one"}

The number of these activity reached ten activities which are: (construction, wholesale and retail trade, repair of motor vehicles and motorcycles, transport and storage, activities of establishing food services, real estate activities, activities of administrative services and support services, other services activities, activities of households which use individuals or producing goods and unspecialized special services, activities of organizations and foreign bodies, and manufacturing), which represent $48 \%$ of the total number of economic activities in the region, which have ability of labor to export its productions into outside Mecca by $9 \%$ of total number of labor in Mecca region, whereas labor, construction activity, wholesale and retail trade, and repair of motor vehicles and motorcycles accounted for the biggest part of that, with a percentage of $55 \%$ of the total activity labor of Quotient larger than "one".

\section{Major economic activities of Location Quotient Equals "one"}

The number of these activities is three activities which are: (water supply and activities of sewage, waste management and treatment, information and communications, and activities of human health and social services) which represents $14 \%$ of the total number of economic activities in the region, and the number of labor in these activities is about 192,400 workers with a percentage of $7 \%$ from the total number of labor in Mecca region.

\section{Major economic activities of Location Quotient smaller than "one"}

The remaining economic activities are primary, which are eight activities as follows: (agriculture, forestry and fishing, mining and utilization of stone pits, financial activities and insurance activities, scientific and technical functional activities, supply of electricity, gas, steam and air conditioning, public administration, defense and compulsory social security, education, and arts, recreation and entertainment) which represents $38 \%$ of total number of economic activities in the region, indicating that Mecca region is repellent to these activity, so it is unattractive to 


\section{International Journal of Science and Research (IJSR) \\ ISSN (Online): 2319-7064 \\ Index Copernicus Value (2013): 6.14 | Impact Factor (2014): 5.611}

investment opportunities and career opportunities, and the percentage of labor in these economic activities which are smaller than "one" equals $30 \%$ of the total number of labor in Mecca region.
The possibility of classifying economic activities sectors of Mecca region onto three main types according to L-Q as shown in tables below:

Table 1: Classifying economic activities sectors by type of investment

\begin{tabular}{|c|c|c|c|}
\hline $\begin{array}{c}\text { The total number } \\
\text { of activity by type } \\
\text { of investment }\end{array}$ & Economic activities & Investment Type & $L Q$ \\
\hline \multirow[t]{10}{*}{$\mathrm{J}$} & Manufacturing & \multirow{10}{*}{$\begin{array}{l}\text { Attractive economic } \\
\text { activities Investment }\end{array}$} & \multirow{10}{*}{$<1$} \\
\hline & Construction & & \\
\hline & Wholesales and retail trade; repair of motor vehicles and motorcycles & & \\
\hline & Transportation and storage & & \\
\hline & Accommodation and food service activities & & \\
\hline & Real estate activities & & \\
\hline & Administrative and support service activities & & \\
\hline & Other service activities & & \\
\hline & $\begin{array}{l}\text { Activities of households as employers; undifferentiated goods-and services-producing } \\
\text { activities of households for won use }\end{array}$ & & \\
\hline & Activities of extraterritorial organizations and bodies & & \\
\hline \multirow{10}{*}{3} & Water supply; sewerage, waste management and remediation activities & \multirow{3}{*}{$\begin{array}{l}\text { Moderate economic } \\
\text { activities }\end{array}$} & \multirow{3}{*}{$=1$} \\
\hline & Information and communication & & \\
\hline & Human health and social work activities & & \\
\hline & Agriculture, forestry and fishing & \multirow{7}{*}{$\begin{array}{l}\text { Repellent economic } \\
\text { activities Investment }\end{array}$} & \multirow{7}{*}{$>1$} \\
\hline & Mining and quarrying & & \\
\hline & Electricity, gs, steam and air conditioning supply & & \\
\hline & Financial and insurance activities & & \\
\hline & Professional, scientific and technical activities & & \\
\hline & Education & & \\
\hline & Arts, entertainment and recreation & & \\
\hline 21 & \multicolumn{3}{|l|}{ Total } \\
\hline
\end{tabular}

Table 2: Classifying economic activities sectors by number of employment-exporting production outside the region

\begin{tabular}{|c|c|c|c|}
\hline $\begin{array}{c}\text { The number of } \\
\text { employment- } \\
\text { exporting } \\
\text { production outside } \\
\text { the region }\end{array}$ & Economic activities & Investment Type & $L Q$ \\
\hline \multirow{10}{*}{268,485} & Manufacturing & \multirow{10}{*}{$\begin{array}{l}\text { Attractive economic } \\
\text { activities Investment }\end{array}$} & \multirow{10}{*}{$<1$} \\
\hline & Construction & & \\
\hline & Wholesales and retail trade; repair of motor vehicles and motorcycles & & \\
\hline & Transportation and storage & & \\
\hline & Accommodation and food service activities & & \\
\hline & Real estate activities & & \\
\hline & Administrative and support service activities & & \\
\hline & Other service activities & & \\
\hline & $\begin{array}{l}\text { Activities of households as employers; undifferentiated goods-and services-producing } \\
\text { activities of households for won use }\end{array}$ & & \\
\hline & Activities of extraterritorial organizations and bodies & & \\
\hline \multirow[t]{3}{*}{0} & Water supply; sewerage, waste management and remediation activities & \multirow{3}{*}{$\begin{array}{c}\text { Moderate economic } \\
\text { activities }\end{array}$} & \multirow{3}{*}{$=1$} \\
\hline & Information and communication & & \\
\hline & Human health and social work activities & & \\
\hline \multirow[b]{7}{*}{0} & Agriculture, forestry and fishing & \multirow{7}{*}{$\begin{array}{l}\text { Repellent economic } \\
\text { activities Investment }\end{array}$} & \multirow[b]{7}{*}{$>1$} \\
\hline & Mining and quarrying & & \\
\hline & Electricity, gs, steam and air conditioning supply & & \\
\hline & Financial and insurance activities & & \\
\hline & Professional, scientific and technical activities & & \\
\hline & $\begin{array}{c}\text { Education } \\
\end{array}$ & & \\
\hline & Arts, entertainment and recreation & & \\
\hline 268,485 & $\begin{array}{ll}\text { Total } \\
\end{array}$ & & \\
\hline
\end{tabular}




\section{International Journal of Science and Research (IJSR) \\ ISSN (Online): 2319-7064 \\ Index Copernicus Value (2013): 6.14 | Impact Factor (2014): 5.611}

Table 3: Classifying economic activities sectors by number of productive employment within the region

\begin{tabular}{|c|c|c|c|}
\hline $\begin{array}{c}\text { The number of productive } \\
\text { employment within the } \\
\text { region }\end{array}$ & Economic activities & Investment Type & $L Q$ \\
\hline \multirow{10}{*}{$1,612,644$} & Manufacturing & \multirow{10}{*}{$\begin{array}{c}\text { Attractive economic activities } \\
\text { Investment }\end{array}$} & \multirow{10}{*}{$<1$} \\
\hline & Construction & & \\
\hline & Wholesales and retail trade; repair of motor vehicles and motorcycles & & \\
\hline & Transportation and storage & & \\
\hline & Accommodation and food service activities & & \\
\hline & Real estate activities & & \\
\hline & Administrative and support service activities & & \\
\hline & Other service activities & & \\
\hline & $\begin{array}{l}\text { Activities of households as employers; undifferentiated goods-and } \\
\text { services-producing activities of households for won use }\end{array}$ & & \\
\hline & Activities of extraterritorial organizations and bodies & & \\
\hline \multirow{3}{*}{192,400} & Water supply; sewerage, waste management and remediation activities & \multirow[t]{3}{*}{ Moderate economic activities } & \multirow[t]{3}{*}{$=1$} \\
\hline & Information and communication & & \\
\hline & Human health and social work activities & & \\
\hline \multirow{7}{*}{877,623} & Agriculture, forestry and fishing & \multirow{7}{*}{$\begin{array}{c}\text { Repellent economic activities } \\
\text { Investment }\end{array}$} & \multirow{7}{*}{$>1$} \\
\hline & Mining and quarrying & & \\
\hline & Electricity, gs, steam and air conditioning supply & & \\
\hline & Financial and insurance activities & & \\
\hline & Professional, scientific and technical activities & & \\
\hline & Education & & \\
\hline & Arts, entertainment and recreation & & \\
\hline 268,485 & Total & & \\
\hline
\end{tabular}

Whereas figures shows the percentage associated to major economic activities in Mecca region according to L-Q and the number of labor productive to outside and inside the territory.

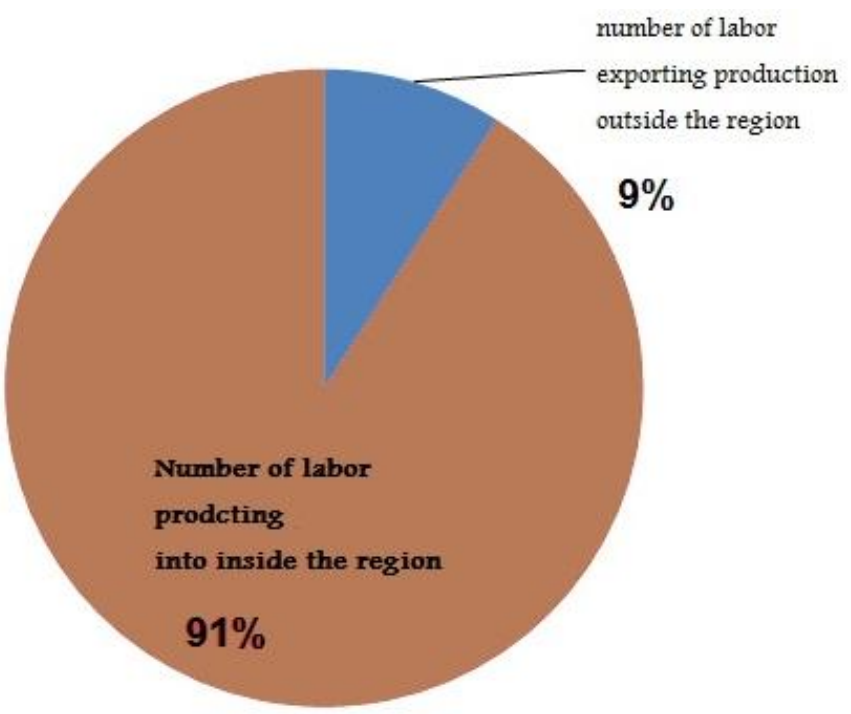

Figure 2: percentages of major economic activities in Mecca region according to number of labor producing to inside and outside the territory

Table 4: The employment producing and exporting

\begin{tabular}{|c|c|}
\hline $\begin{array}{c}\text { Number of labor producing } \\
\text { to inside region }\end{array}$ & $\begin{array}{c}\text { Number of labor exporting } \\
\text { production }\end{array}$ \\
\hline $2,682,667$ & 268,485 \\
\hline
\end{tabular}

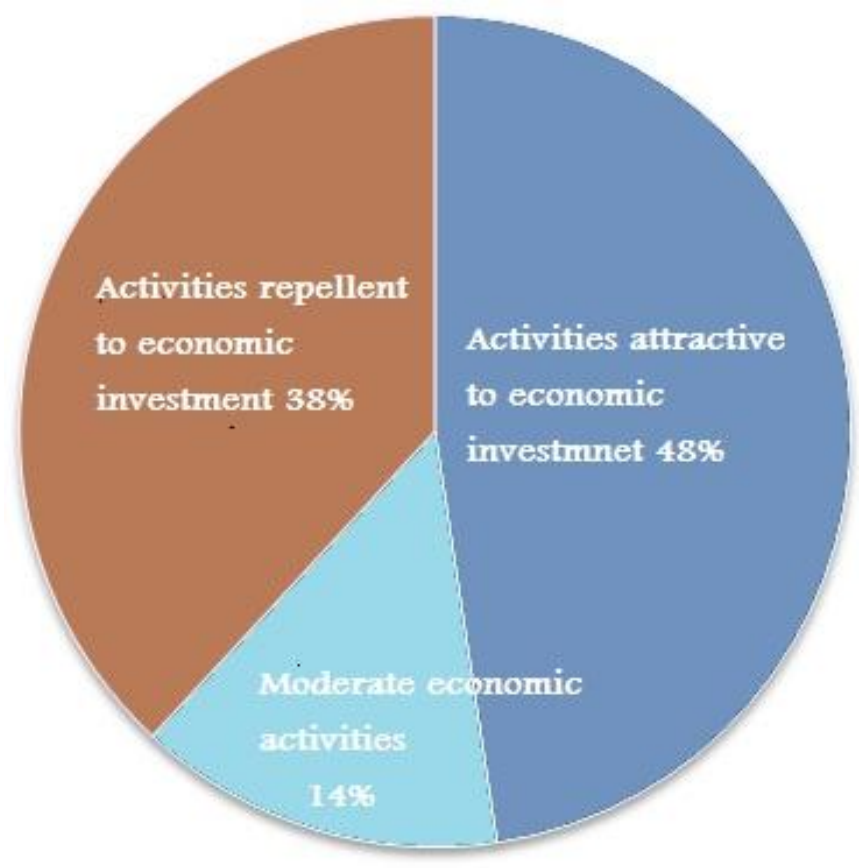

Figure 3: percentages of major economic activities in Mecca region according to $\mathrm{L}-\mathrm{Q}$

Results of Location Quotient have been presented and discussed in order to identify the possibilities and elements of spatial economic development of the region, by identifying the results of labor concentration in the region (Share) which can be summarized into three main types as follows:

- High concentration of labor:

Through labor concentration in the major economic activities in the region with more than $(10 \%)$ which represents $52.9 \%$ of the total of labor concentration in the region which are 4 activities distributed as follows: (wholesale and retail trade 


\section{International Journal of Science and Research (IJSR) \\ ISSN (Online): 2319-7064 \\ Index Copernicus Value (2013): 6.14 | Impact Factor (2014): 5.611}

activity, and repair of motor vehicles and motorcycles with $15.9 \%$, followed by construction with $14.7 \%$, then public administration and social security activities with $11.7 \%$, followed by education activity with $10.6 \%$ ). Whereas activity of wholesale and retail trade, repair of motor vehicles and motorcycles, and construction are two main sectors attracting economic investment, but other two activities are primary sectors which are public administration, social security, and education activities.

- Moderate concentration of labor:

Through labor concentration in the major economic activity in the region between $(5 \%-10 \%)$ which represents $23.7 \%$ of the total concentration of labor in the region, which are 3 activities, distributed as follows: (manufacturing with 9.4\%, followed by activities of households which use individuals or producing goods and unspecialized special services with $9.3 \%$, then activities of human health and social services with $5 \%$ ), whereas manufacturing and activities of households which use individuals or producing goods and unspecialized special services are two main sectors attracting economic investment, but other activity is a primary sector which is activities of human health and social services.

- Low concentration of labor:

Through concentration of labor in the major economic activity in the region, with less that (5\%) represents $23.4 \%$ of the total concentration of labor in the region, which are 13 activities representing the remaining major economic activities in the region, whereas transport and storage activity, residence and food services, real estate activity, activity of administrative services and support services, other services activity, activity of organizations and foreign bodies are main sectors attracting economic investment.

Table (5) shows the percentage of concentration of labor in economic activities and the rate of this concentration in the region. Which as follows:

Table 5: percentage of concentration of labor in economic activities

\begin{tabular}{|c|c|c|c|c|}
\hline $\begin{array}{l}\text { Total Percentage } \\
\text { of labor } \\
\text { concentration in } \\
\text { economic activity } \\
\text { from total labor } \\
\text { conc. In the } \\
\text { region } \\
\end{array}$ & erahS\% & Economic activities & \begin{tabular}{|c|} 
Percentage of \\
labor \\
concentration in \\
economic \\
activity
\end{tabular} & $\begin{array}{c}\text { Conc. of } \\
\text { labor } \\
\text { (Share) }\end{array}$ \\
\hline \multirow[t]{4}{*}{$\% 52.90$} & $\% 15.90$ & Wholesale and retail trade; repair of motor vehicles and motorcycles & \multirow{4}{*}{$\begin{array}{c}\text { More than } \\
10 \%\end{array}$} & \multirow[t]{4}{*}{ High } \\
\hline & $\% 14.70$ & Construction & & \\
\hline & $\% 11.70$ & Public administration and defense; compulsory social security & & \\
\hline & $\% 10.60$ & Education & & \\
\hline \multirow[t]{3}{*}{$\% 23.70$} & $\% 9.40$ & Manufacturing & \multirow[t]{3}{*}{$-5 \%-10 \%$} & \multirow[t]{3}{*}{ Moderate } \\
\hline & $\% 9.30$ & $\begin{array}{l}\text { Activities of households as employers; undifferentiated goods-and services- } \\
\text { producing activities of households for won use }\end{array}$ & & \\
\hline & $\% 5.00$ & Human health and social work activities & & \\
\hline \multirow[t]{14}{*}{$\% 23.40$} & $\% 4.80$ & Transportation and storage & \multirow{5}{*}{$\begin{array}{c}\text { Less than } \\
10 \%\end{array}$} & \multirow[t]{5}{*}{ Low } \\
\hline & $\% 3.90$ & Agriculture, forestry and fishing & & \\
\hline & $\% 3.60$ & Accommodation and food service activities & & \\
\hline & $\% 2.40$ & Administrative and support service activities & & \\
\hline & $\% 2.20$ & Other service activities & & \\
\hline & $\% 1.30$ & Professional, scientific and technical activities & \multirow{9}{*}{$\begin{array}{c}\text { Less than } \\
10 \%\end{array}$} & \multirow[t]{9}{*}{ Low } \\
\hline & $\% 1.20$ & Real estate activities & & \\
\hline & $\% 1.10$ & Financial and insurance activities & & \\
\hline & $\% 0.90$ & Information and communication & & \\
\hline & $\% 0.60$ & Mining and quarrying & & \\
\hline & $\% 0.50$ & Water supply; sewerage, waste management and remediation activities & & \\
\hline & $\% 0.40$ & Electricity, gas, steam and air conditioning supply & & \\
\hline & $\% 0.20$ & Activities of extraterritorial organizations and bodies & & \\
\hline & $\% 0.10$ & Arts, entertainment and recreation & & \\
\hline
\end{tabular}

The following Figure Shows the number of employment, according Basic and non-Basic economic sectors: 


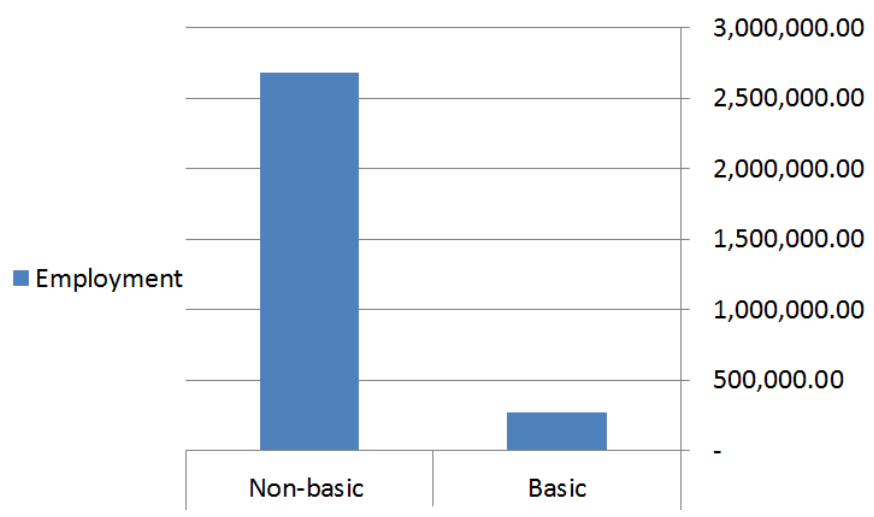

Figure 4: The number of employment, according Basic and non-Basic economic sectors

The figure below shows the rate of economic sectors in Mecca and compare it with economic sectors in Saudi Arabia:

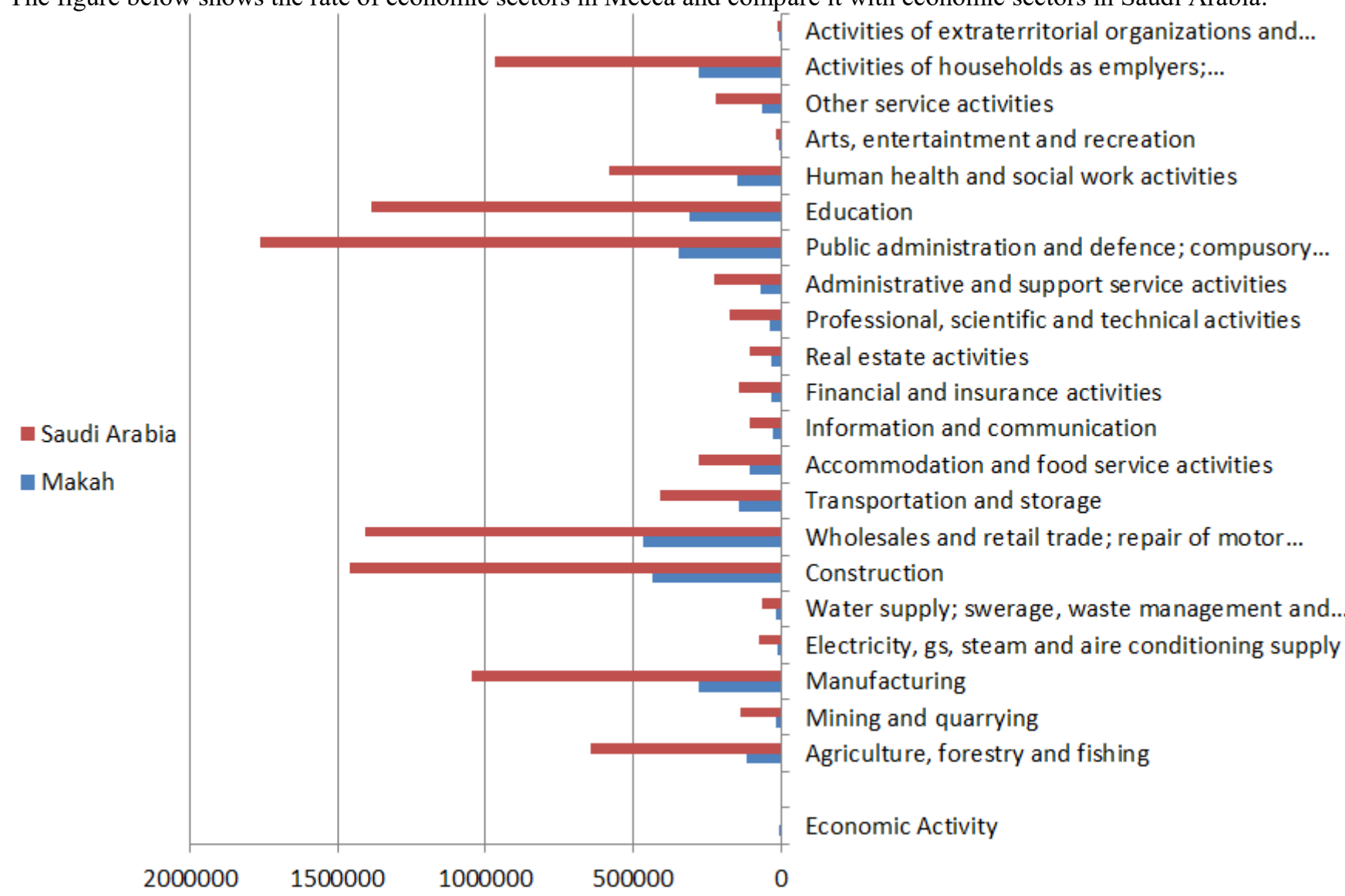

Figure 5: The economic sectors in Mecca and the economic sectors in Saudi Arabia

\section{Conclusion and Recommendations}

Results of study associated to studying and analyzing economic structure of Mecca region have been presented and discussed, in order to identify the possibilities and elements of spatial economic development of the region for year 2015. Most important results and recommendations can be summarized as follows:

5.1 The activities of wholesale and retail trade, repair of motor vehicles and motorcycles and construction have occupied about $30.6 \%$ of total number of labor in Mecca region, reflecting the power of these economic activities in attracting investments capital, career opportunities and the income for the regions and its residents. So the study recommends focusing on these activities and adopting developmental policies and strategies sustaining its growth and development.

5.2 Agriculture, forestry and fishing, mining and utilization of stone pits, financial activities and insurance activities, scientific and technical functional activities, supply of electricity, gas, steam and air conditioning, public administration, defense and compulsory social security, education, and arts, recreation and entertainment activities are considered activities in the presence of spatial elements (geographic location and promising touristic economic regions in Mecca especially with high level of developmental activities in the region), insuring the presence of promising future investment opportunities for these activities in the region. So the study recommends adopting of motivational policies and strategies enhancing the region ability to develop these opportunities through the private sector.

\section{Volume 4 Issue 12, December 2015}




\section{International Journal of Science and Research (IJSR) \\ ISSN (Online): 2319-7064}

Index Copernicus Value (2013): 6.14 | Impact Factor (2014): 5.611

5.3 in the presence of low labor concentration for the major activities relative to the number of labor in the region, with important spatial elements, and with largely concentration of labor in primary activities, it is important to concern about economic activities and to coordinate balance between these activities to be of investment opportunities and benefits which cannot be neglected as a major motive of economic development for Mecca region. Private sector can play a major role in development of the region.

5.4 to reach more trusted and accurate future economic developmental strategy for Mecca region; many economic indications must be used, in addition to number of labor indicators, for example; (number of institutions, labor wages, incomes and sales of different economic activities, and rate and amount of production) for each economic activity in the studied region, with limitation of available data from economic sectors, and the type of different economic activities before. In considering governmental departments in general, and statistics and information survey in particular, it has been focused on the number of labor in different economic activities as a major indicator in studying and analyzing economic developmental possibilities of Mecca region, which indicates poor data provided by associated governmental authorities.

\section{References}

[1] M. Al Ghaith,"Assessment of applying regional development plans in Saudi Arabia," Medina and Riyadh regions - analyzing and comparing study Master - King Saud University, Riyadh, 2011.

[2] www.maphill.com

[3] Department of Statistics and Information, Statistics population of Saudi Arabia, Check-in date: 6 August 2009.

[4] M. Al-Sharif,"problem of urban change for Saudia cities: local perspective," Umm Al Qura University, Arabic References in 2000.

[5] Saudi Geological Survey, Kingdom of Saudi Arabia: Facts and Figures / Saudi Geological Survey - Jeddah, 2011.

[6] J. Friedmann, “Regional Development Policy,'”: A Case Study of Venezuela", the MIT Press, Cambridge, 1966.

[7] G. Myrdal,"Economic Theory and the Under Developed Regions", Methuen and Co. Ltd, London, 1957.

[8] H. Armstrong, and J. Taylor, "Regional Economic and Policy”, 3rd Ed Blackwell Publishers Ltd , Oxford, 2000.

[9] A. Atkinson, "The Economics of Inequality", Oxford University Press, Oxford, 1983.

[10] M. Abdulrahman, and V. Almarikhi, and A. Alkhudari,"Urban Development Strategy of Kingdom of Saudi Arabia," in book of Urban Development in Saudi Arabia: Opportunities and Challenges, edited by Salih Hathloul and Narayanan Aadadan, Dar Alshn: Riyadh, 1989.

[11] A. Howaish,"The Saudi system of rural and urban national strategy: an analytical study of the population of rural communities in the eastern region," Building Technology magazine, 12.23: 28-43, 2011.
[12] M. Mushkhus, "Role of development plans in managing regional balance in Kingdom of Saudi Arabia: Evaluation Study to regional experience of Kingdom between the years 1970-1994," Geography Research, Saudi Geographical Association, 21.36: 78-112, 2001.

[13] A. Howaish, "the Saudi regional urban system and the concept of the central place: analytical study of the concentrations of population in the eastern region," Building Technology Magazine, 9.20: 26-37, 2010.

[14] M. Abdulrahman, V. Almarikhi, and A. Alkhudari,"urban development strategy of the Kingdom of Saudi Arabia", in the book of Urban Development in Saudi Arabia: Opportunities and Challenges, edited by Salih Hathloul and Narayanan Aadadan, Dar Alshn: Riyadh, 1989.

[15] M. Mushkhus, "Role of Petrochemical Industries in regional development in Alsharqiya and Medina regions in Saudi Arabia: assessment study of the experiment of Jubail and Yanbu cities according to growth pole theory ,, Journal of the Faculty Arts and Sciences, King Abdul Aziz University, 18.36: 78-112, 1998.

[16] A. Howaish,"spatial variation of health services in the Kingdom of Saudi Arabia: an analytical study of the period between 1992 to 2009", Journal of the Gulf and Arabian Peninsula Studies, University of Kuwait, accepted for publication in the July 3, 2013.

[17] A. . Al-Jarallah, and M. Aldioufi, "the regional variation in the Kingdom of Saudi Arabia: an analysis of the labor environment", Journal of Documentation and Humanities Research Center, Qatar University, 10.22: 76-98, 1998.

[18] S. Hathloul and N. Adidan,"Urban Development in Saudi Arabia: Opportunities and Challenges", Dar Alshn, Riyadh, 1999.

[19] M. Mackie,"size distribution of cities in Saudi Arabia," a symposium of Saudi cities: its spread and internal installation. Department of Geography. King Saud University, Riyadh, 1983.

[20] S. Mackie "'small cities are the hope of the future: Hano Mano Madin-balanced: An Empirical Study on Saudi Arabia," the Arab Journal for Humanities, 8.31: 34-78. 1988.

[21] The Ministry of Economy and Planning, Department of Statistics and Information, "Statistical Yearbook", the Kingdom of Saudi Arabia, Riyadh, 1992 and 2009.

[22] F. Aburadi,"spatial distributions - study in ways of statistical description and numerical analysis in geography," University Knowledge House, Alexandria, 1991.

[23] D. Rondinethe, "An Applied Regional Methods of Analysis: The Spatial Dimensions of Development Policy”, Westview Press, London,1985.

[24] R. Klosterman, "Community and Analysis Planning Techniques”, 1990.

\section{Author Profile}

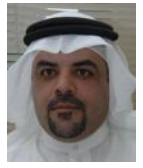

Abdulkarim K. Alhowaish - Following his Ph.D in Regional Economic Development from University of Guelph in 2007, Dr. Alhowaish is currently an associate Professor in Department of Urban and Regional Planning, College of Architecture and 
Planning, University of Dammam. Dr. Alhowaish has acted as a director manager for Ministry of Municipal and Rural Affairs on developing the National Strategy for Municipal Services Delivery in Saudi Rural Areas. He is currently a consultant for Ministry of Economic and Planning on developing the 10th National Development Plan. Dr. Alhowaish has more than 25 scientific publication and conference papers and five funded development project. His research interest is the economics of regions, both urban and rural regions. Recently, Dr. Alhowaish received the distinguished Professor Award from University of Dammam in October 7, 2013.

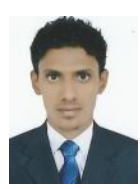

Ahmed S. Bafgeesh - Received the B.S. in Architecture from Department of Architecture and Environmental Planning, College of Engineering and Petroleum, University of Hadramout in 2012, Eng. Bafgeesh is currently study master degree in the Department of Urban and Regional Planning, the College of Architecture and Planning, the University of Dammam, Eng. Bafgeesh has acted as a Demonstrator in the architecture department at the University of Hadramout, and he worked as an architect. Eng. Bafgeesh attended a number of scientific conferences and participated in different organizing committees. He received the Youth Creativity for Scientific Excellence Award from World Assembly of Muslim Youth in October 22, 2015.

Abdualrhman M. Algarbua - Received the B.S. in urban and regional planning from Department of Urban and Regional Planning, College of Architecture and Planning, University of Dammam, in 201\&, Eng. Algarbua is currently study master degree in the Department of Urban and Regional Planning, the College of Architecture and Planning, the University of Dammam. He attended a number of scientific conferences and participated in different organizing committees. 